\title{
Efficacy of Health Belief Model-Based Intervention in Enhancing Breast Cancer Screening Behaviors among Women at Al-Najaf Al-Ashraf City
}

\author{
Alaa Abdul-hadi Kadhim ${ }^{1}$, ArkanBahlol Naji ${ }^{2}$ \\ ${ }^{1}$ M.Sc. N(c), Research Scholar, University of Baghdad, College of Nursing, ${ }^{2}$ Professor (PhD), University of \\ Baghdad, College of Nursing, Community Health Nursing Department
}

\begin{abstract}
Background: Breast cancer is disease in which cells in breast tissue change and divide uncontrolled, resulting in a lump or mass. This study aims to determine the efficacy of health belief model-based intervention in enhancing women's breast cancer screening behaviors.
\end{abstract}

Method: A randomized controlled trial was conducted using the Health Belief Model. The study included a systematic random sample of 110 women. Women who age 22-68-years were selected from Banks in AlNajaf Al-Ashraf City.

Data were collected through a self-report instrument that includes women's sociodemographic characteristics of age, marital status, and economic status, the Perceived Susceptibility Scale, the Perceived Benefits Scale, the Self-Efficacy Scale, the Health Motivation, the Perceived Severity Scale, and the Perceived Barriers Scale. Data were analyzedusing the statistical package forsocial sciences, version 26.

The study results revealed that HBM-based intervention was efficacious in enhancing the Perceived Susceptibility, the Perceived Benefits, the Self-Efficacy, the Health Motivation, the Perceived Severity, and the Perceived Barriers for women in the study group. The researcher concluded that the HBM-based intervention we as efficacious in enhancing women's screening behaviors for breast cancer.

Conclusion: The researcher concluded that the HBM-based intervention was effective in enhancing women's breast cancer screening behaviors.

Keywords: Health Belief Model-Based Intervention, Breast Cancer, Screening Behaviors.

\section{Introduction}

Cancer is a present of abnormal cells that spread and characterized by the uncontrolled growth and result in death If the spread is not controlled ${ }^{(1)}$. Globally, more than half new cases deaths from cancer among worldwide of men and women combined in 2018 are estimated to occur in Asia, because the region has nearly $60 \%$ of the global population ${ }^{(9)}$.

Breast cancer is disease in which cells in breast tissue change and divide uncontrolled, resulting in a lump or mass. Most breast cancers begin in the lobules (milk glands) or in the ducts that connect the lobules to the nipple ${ }^{(1)}$ during 2013 year 4,529women with breast cancer were forming loss of life, and 909 ladies died from that disorder due to late analysis and insufficient administration.(10). According of American Cancer Society (ACS) there are three screening method are BSE, clinical breast examination, mammography, Mammography is more effective way for early detection of breast cancer ${ }^{(3)}$. Breast self-examination make women aware of their breasts so as to detect changes early ${ }^{(4)}$. In health education, the Champion Health Belief Model (CHBM) is theoretical models used to study the health behavior that can be introduced by Champion in the 1980s. This model has been widely used by researchers (5). When people find themselves at risk for the disease (Perceived Susceptibility), realize that the disease has serious potential consequences (Perceived Seriousness), believe that prevention would have positive results 
(Perceived Benefits), barriers of that behavior is fewer than obtained benefits (Perceived Barriers), and believe that they have the ability to perform health behavior activities (Self-Efficacy), it would be more probable for them to accomplish this behavior. ${ }^{(6)}$

A randomized controlled trial design was used to guide this study in Banks of Al-Raafidayn/branch Al-Amir, Al-Ghuri, Seven, and Muslim Bin Aqeel at Al-Najaf Al-Ashraf for the period from February 1th, 2020 to thirty of April, 2020 on probability randomized sampling method (systematic random samplings method) to recruit study subjects. Data were collected through a self-report instrument that includes First part: The demographic characteristics of the nursing staff (age, marital status, economic status).

Second part: The Perceived Susceptibility Scale, The Perceived Benefits Scale, Self-Efficacy Scale, Health Motivation, The Perceived Severity Scale, and The Perceived Barriers Scale

The validity of the questionnaire and the educational program were verified by presenting it to (9) experts. The sample has received a pre-test, intervention based health belief model, and post-test I, Post- test II. Descriptive and inferential statistics were used to analyze the results

\section{Method}

A randomized controlled trial design was used in this study (two groups; pretest, posttest I, Posttest II) in Banks of Al-Raafidayn/branch Al-Amir, Al-Ghuri,, Seven, and Muslim Bin Aqeel at Al-Najaf Al-Ashraf for the period from February 1th, 2020 to thirty of April, 2020 on probability randomized sampling method (systematic random samplings method) to recruit study subjects. Data were collected through a self-report instrument that includes First part: The demographic characteristics of the nursing staff (age, marital status, economic status).

Second part: The Perceived Susceptibility Scale, The Perceived Benefits Scale, Self-Efficacy Scale, Health Motivation, The Perceived Severity Scale, and The Perceived Barriers Scale

The validity of the questionnaire and the educational program were verified by presenting it to (9) experts. The sample has received a pre-test, intervention based health belief model, and post-test I, Post- test II. Descriptive and inferential statistics were used to analyze the results of the study using the Statistical Package of Social Sciences (SPSS) version 26.

\section{Results}

Table 1. Participants' Socio-demographic Characteristics

\begin{tabular}{|l|c|c|c|c|}
\hline \multirow{2}{*}{} & \multicolumn{2}{|c|}{ Study (N=55) } & \multicolumn{2}{c|}{ Control (N = 55) } \\
\cline { 2 - 5 } & Frequency & Percent & Frequency & Percent \\
\hline Age (Years) & & & & \\
$22-32$ & 11 & 20.0 & 12 & 21.8 \\
$33-43$ & 14 & 25.5 & 15 & 27.3 \\
$44-54$ & 25 & 45.4 & 22 & 40.0 \\
$55-68$ & 5 & 9.1 & 6 & 10.9 \\
\hline Mean (SD) & 41.21 & 10.32 & 41.76 & \\
\hline Marital Status & & & & 5.17 \\
Not married & 15 & 27.3 & 3 & 89.1 \\
Married & 34 & 61.8 & 49 & 1.8 \\
Divorced & 5 & 9.1 & 2 & 3.6 \\
Separated & 1 & 1.8 & 2 & \\
\hline
\end{tabular}

Table (1) The age mean for participants in the study group is $41.21 \pm 10.32$; more than two-fifth age 44-55-years $(\mathrm{n}=25 ; 45.4 \%)$, followed by those who age 33-43-years $(\mathrm{n}=14 ; 25.5 \%)$, those who age 22-32-years $(\mathrm{n}=11 ; 20.0 \%)$, and those who age 55-68-years $(\mathrm{n}=5$; $9.1 \%)$.
For the control group, the age mean is $41.76 \pm 10.17$; two-fifth age 44-54-years $(n=22 ; 39.5 \%)$, followed by those who age $33-43$-years $(n=15 ; 27.3 \%)$, those who age 22-32-years $(\mathrm{n}=12 ; 21.8 \%)$, and those who age 55-68-years $(\mathrm{n}=6 ; 10.9 \%)$. 
Table 2. Within-subjects for the Health Motivation

\begin{tabular}{|c|c|c|c|c|c|c|c|}
\hline \multicolumn{8}{|c|}{ Multivariate Tests ${ }^{\mathbf{a}}$} \\
\hline \multicolumn{2}{|l|}{ Effect } & Value & $\mathbf{F}$ & Hypothesis df & Error df & Sig. & Partial Eta Squared \\
\hline \multirow{4}{*}{$\begin{array}{l}\text { HM } \\
\text { (Study) }\end{array}$} & Pillai's Trace & .875 & $186.222^{b}$ & 2.000 & 53.000 & .000 & .875 \\
\hline & Wilks' Lambda & .125 & $186.222^{b}$ & 2.000 & 53.000 & .000 & .875 \\
\hline & Hotelling's Trace & 7.027 & $186.222^{b}$ & 2.000 & 53.000 & .000 & .875 \\
\hline & Roy's Largest Root & 7.027 & $186.222^{b}$ & 2.000 & 53.000 & .000 & .875 \\
\hline \multicolumn{2}{|l|}{ Effect } & Value & $\mathbf{F}$ & Hypothesis df & Error df & Sig. & Partial Eta Squared \\
\hline \multirow{4}{*}{$\begin{array}{l}\mathrm{HM} \\
\text { (Control) }\end{array}$} & Pillai's Trace & .261 & $9.352^{b}$ & 2.000 & 53.000 & .000 & .261 \\
\hline & Wilks' Lambda & .739 & $9.352^{\mathrm{b}}$ & 2.000 & 53.000 & .000 & .261 \\
\hline & Hotelling's Trace & .353 & $9.352^{\mathrm{b}}$ & 2.000 & 53.000 & .000 & .261 \\
\hline & Roy's Largest Root & .353 & $9.352^{\mathrm{b}}$ & 2.000 & 53.000 & .000 & .261 \\
\hline
\end{tabular}

a. Design: Intercept Within Subjects Design: SE for BSE, b. Exact statistic

There are significant differences in the values of the HM for BSE over time for participants both in the study and control groups $(\mathrm{F}=186.222, \mathrm{df}=2, \mathrm{p}<.05$ vs. $\mathrm{F}=9.352, \mathrm{df}=2, \mathrm{p}<.05)$.

Table 3. Within-subjects for the Perceived Susceptibility for contracting breast cancer

\begin{tabular}{|c|c|c|c|c|c|c|c|}
\hline \multicolumn{8}{|c|}{ Multivariate Tests ${ }^{\mathbf{a}}$} \\
\hline \multicolumn{2}{|l|}{ Effect } & Value & $\mathbf{F}$ & Hypothesis df & Error df & Sig. & Partial Eta Squared \\
\hline \multirow{4}{*}{ SE (Study) } & Pillai's Trace & .927 & $339.015^{\mathrm{b}}$ & 2.000 & 53.000 & .000 & .927 \\
\hline & Wilks' Lambda & .073 & $339.015^{\mathrm{b}}$ & 2.000 & 53.000 & .000 & .927 \\
\hline & Hotelling's Trace & 12.793 & $339.015^{b}$ & 2.000 & 53.000 & .000 & .927 \\
\hline & Roy's Largest Root & 12.793 & $339.015^{\mathrm{b}}$ & 2.000 & 53.000 & .000 & .927 \\
\hline \multicolumn{2}{|l|}{ Effect } & Value & $\mathbf{F}$ & Hypothesis df & Error df & Sig. & Partial Eta Squared \\
\hline \multirow{4}{*}{$\begin{array}{l}\text { SE } \\
\text { (Control) }\end{array}$} & Pillai's Trace & .123 & $3.723^{\mathrm{b}}$ & 2.000 & 53.000 & .031 & .123 \\
\hline & Wilks' Lambda & .877 & $3.723^{\mathrm{b}}$ & 2.000 & 53.000 & .031 & .123 \\
\hline & Hotelling's Trace & .141 & $3.723^{\mathrm{b}}$ & 2.000 & 53.000 & .031 & .123 \\
\hline & Roy's Largest Root & .141 & $3.723^{\mathrm{b}}$ & 2.000 & 53.000 & .031 & .123 \\
\hline
\end{tabular}

a. Design: Intercept Within Subjects Design: SE for BSE, b. Exact statistic

There are significant differences in the values of the Perceived Susceptibility for contracting breast cancer over time for participants both in the study and control groups $(\mathrm{F}=339.015, \mathrm{df}=2, \mathrm{p}<.05 \mathrm{vs} . \mathrm{F}=3.723, \mathrm{df}=2, \mathrm{p}<.05)$.

Table 4. Within-subjects for the Perceived Severity of breast cancer

\begin{tabular}{|c|c|c|c|c|c|c|c|}
\hline \multicolumn{8}{|c|}{ Multivariate Tests ${ }^{\mathrm{a}}$} \\
\hline \multicolumn{2}{|l|}{ Effect } & Value & $\mathbf{F}$ & Hypothesis df & Error df & Sig. & Partial Eta Squared \\
\hline \multirow{4}{*}{$\begin{array}{l}\text { Severity } \\
\text { (Study) }\end{array}$} & Pillai's Trace & .834 & $133.393^{b}$ & 2.000 & 53.000 & .000 & .834 \\
\hline & Wilks' Lambda & .166 & $133.393^{b}$ & 2.000 & 53.000 & .000 & .834 \\
\hline & Hotelling's Trace & 5.034 & $133.393^{b}$ & 2.000 & 53.000 & .000 & .834 \\
\hline & Roy's Largest Root & 5.034 & $133.393^{b}$ & 2.000 & 53.000 & .000 & .834 \\
\hline \multicolumn{2}{|l|}{ Effect } & Value & $\mathbf{F}$ & Hypothesis df & Error df & Sig. & Partial Eta Squared \\
\hline \multirow{4}{*}{$\begin{array}{l}\text { Severity } \\
\text { (Control) }\end{array}$} & Pillai's Trace & .155 & $4.879^{\mathrm{b}}$ & 2.000 & 53.000 & .011 & .155 \\
\hline & Wilks' Lambda & .845 & $4.879^{\mathrm{b}}$ & 2.000 & 53.000 & .011 & .155 \\
\hline & Hotelling's Trace & .184 & $4.879^{\mathrm{b}}$ & 2.000 & 53.000 & .011 & .155 \\
\hline & Roy's Largest Root & .184 & $4.879^{\mathrm{b}}$ & 2.000 & 53.000 & .011 & .155 \\
\hline
\end{tabular}

a. Design: Intercept Within Subjects Design: Perceived Severity of breast cancer, b. Exact statistic 
There are significant differences in the values of the Perceived Severity of breast cancer over time for participants both in the study and control groups $(\mathrm{F}=133.393$, $\mathrm{df}=2, \mathrm{p}<.05 \mathrm{vs} . \mathrm{F}=4.879, \mathrm{df}=2, \mathrm{p}<.05)$.

Table 5. Within-subjects for the Perceived Benefits of BSE

\begin{tabular}{|c|c|c|c|c|c|c|c|}
\hline \multicolumn{8}{|c|}{ Multivariate Tests $^{\mathrm{a}}$} \\
\hline \multicolumn{2}{|l|}{ Effect } & Value & $\mathbf{F}$ & Hypothesis df & Error df & Sig. & Partial Eta Squared \\
\hline \multirow{4}{*}{$\begin{array}{l}\text { Benefits } \\
\text { (Study) }\end{array}$} & Pillai's Trace & .895 & $226.298^{b}$ & 2.000 & 53.000 & .000 & .895 \\
\hline & Wilks' Lambda & .105 & $226.298^{\mathrm{b}}$ & 2.000 & 53.000 & .000 & .895 \\
\hline & Hotelling's Trace & 8.540 & $226.298^{b}$ & 2.000 & 53.000 & .000 & .895 \\
\hline & Roy's Largest Root & 8.540 & $226.298^{\mathrm{b}}$ & 2.000 & 53.000 & .000 & .895 \\
\hline \multicolumn{2}{|l|}{ Effect } & Value & $\mathbf{F}$ & Hypothesis df & Error df & Sig. & Partial Eta Squared \\
\hline \multirow{4}{*}{$\begin{array}{l}\text { Benefits } \\
\text { (Control) }\end{array}$} & Pillai's Trace & .206 & $6.868^{\mathrm{b}}$ & 2.000 & 53.000 & .002 & .206 \\
\hline & Wilks' Lambda & .794 & $6.868^{b}$ & 2.000 & 53.000 & .002 & .206 \\
\hline & Hotelling's Trace & .259 & $6.868^{\mathrm{b}}$ & 2.000 & 53.000 & .002 & .206 \\
\hline & Roy's Largest Root & .259 & $6.868^{\mathrm{b}}$ & 2.000 & 53.000 & .002 & .206 \\
\hline
\end{tabular}

a. Design: Intercept Within Subjects Design: Perceived Benefits of BSE, b. Exact statistic

There are significant differences in the values of the Perceived Benefits of BSE over time for participants both in the study and control groups $(\mathrm{F}=226.598, \mathrm{df}=2, \mathrm{p}<.05$ vs. $\mathrm{F}=6.868, \mathrm{df}=2, \mathrm{p}<.05$ ).

\section{Discussion}

Concerning the values of the Health Motivation (HM) for BSE for the study group, there was a noticeably increase by time compared to the control group. Also, there was a priori significant difference in the HM for BSE over time for participants in the study group. The omnibus effect (measure of association) for this analysis is .567 , which indicates that approximately $56 \%$ of the total variance in the HME for BSE values is accounted for by the variance in the administered intervention. For the control group, there was no significant difference in the HM for BSE over time. Furthermore, there was a constant difference in participants' HM for BSE in the study group over time. These findings reflect the positive, constant effect of the administered intervention in enhancing participants' HM for BSE. These findings are consistent (8)with who concluded that The results of the data analysis showed a statistically significant difference between the intervention and control groups regarding the mean scores of knowledge and motivation before the intervention $(\mathrm{P}>0.05)$ and after intervention the mean score and standard deviation for intervention group $40.84 \pm 6.21$ while control group $38 \pm 6.47$.

Regarding the values of the Perceived Susceptibility for developing breast cancer for the study group, there was a noticeably increase by time compared to the control group. Also, there was a significant difference in the Perceived Susceptibility for developing breast cancer over time for participants in the study group. The omnibus effect (measure of association) for this analysis is .521, which indicates that approximately $56 \%$ of the total variance in the Perceived Susceptibility for developing breast cancer values is accounted.

for by the variance in the administered intervention. For the control group, there was no significant difference in the Perceived Susceptibility for developing breast cancer over time. Furthermore, there was a constant difference in participants' Perceived Susceptibility for developing breast cancer in the study group over time. These findings reflect the positive, constant effect of the administered intervention in enhancing participants' Perceived Susceptibility for developing breast cancer. These findings are consistent with (7) who concluded that mean score and standard deviation for experimental $4.33 \pm 28.14$ and p-value 0.007 while in control group $4.32 \pm 14.79$ and 0.23 The results of the present study indicate a significant increase in the post-test mean scores on perceived susceptibility and severity in the experimental group compared to the control .

Regarding the values of the Perceived Severity of 
breast cancer for the study group, there was a noticeably increase by time compared to the control group. Also, there was a significant difference in the Perceived Severity of breast cancer over time for participants in the study group. The omnibus effect (measure of association) for this analysis is .371 , which indicates that approximately $37 \%$ of the total variance in the Perceived Severity of breast cancer values is accounted for by the variance in the administered intervention. For the control group, there was no significant difference in the Perceived Severity of breast cancer over time. Furthermore, there was a constant difference in participants' Perceived Severity of breast cancer in the study group over time. These findings reflect the positive, but not constant effect of the administered intervention in enhancing participants' Perceived Severity of breast cancer. These findings are consistent with(7) who concluded that the mean score and standard deviation for experimental group. $4.01 \pm 26.75$ and $\mathrm{p}<0.001$ and control group $1.67 \pm 84.10$ and p-value 0.36 after intervention with respect to the values of the Perceived Benefits of BSE for the study group, there was a noticeably increase by time compared to the control group. Also, there was a significant difference in the Perceived Benefits of BSE over time for participants in the study group. The omnibus effect (measure of association) for this analysis is .550 , which indicates that approximately $55 \%$ of the total variance in the Perceived Benefits of BSE values is accounted for by the variance in the administered intervention. For the control group, there was no significant difference in the Perceived Benefits of BSE over time. Furthermore, there was a constant difference in participants' Perceived Benefits of BSE in the study group over time. These findings reflect the positive, constant effect of the administered intervention in enhancing participants' Perceived Benefits of BSE. These findings are consistent with (7)who concluded that the study results demonstrated a significant increase in the post-test mean score of perceived benefits in the experimental group compared to the control group. Mean \pm SD $1.23 \pm 22.20$ for the experimental group and the control group $1.67 \pm 84.10$.

\section{Conclusion}

1. The Customer Satisfaction Scale is very important to assess the quality of health services and can predict compliance and use with international standards for quality of services.

2. The study found that most primary health care centers are located in densely populated areas. Therefore, primary health care services are adequately provided.

Recommendations: The researchers recommend it is necessary to incorporate health belief model-based interventions into the curricula of graduate programs in Iraq.

Encourage graduate students to adopt interventionbased studies in their future proposed research.

Conflict of Interest: The researchers confirm that there is no any conflict of interest.

Source of Funding: This study is self-funded.

Ethical Clearance: The researchers obtained the ethical approval from the University of Baghdad, College of Nursing.

\section{References}

1. American cancer society. Basic cancer facts. 2019. Retrieved from: https://www.cancer.org/ content/dam/cancer-org/research/cancer-facts-andstatistics/annual-cancer-facts-and-figures/2019/ cancer-facts-and-figures-2019

2. Ghaffari M, Esfahani SN, Rakhshanderou S, Koukamari PH. Evaluation of Health Belief Model-Based intervention on breast cancer screening behaviors among health volunteers. Journal of cancer education: the official journal of the American Association for Cancer Education [Internet]. 2019 Oct [cited 2020 Nov 2];34(5):90412. Available from: https://search-ebscohostcom.ezproxy.okcu.edu/login.aspx?direct=true \& $\mathrm{db}=$ mnh \& $\mathrm{AN}=29987586$ \& site $=$ ehost-live

3. Birhane N, Mamo A, Girma E, Asfaw S. Predictors of breast self - examination among female teachers in Ethiopia using health belief model. Archives of public health $=$ Archives belges de santepublique [Internet]. 2015 Aug 27 [cited 2020 Nov 2];73(1):39. Available from: https:// search-ebscohost-com.ezproxy.okcu.edu/login. aspx?direct=true \& db=mnh \& $\mathrm{AN}=26380083$ \& site $=$ ehost-live

4. Akhtari-Zavare M, Latiff LA, Juni MH, Said SM, Ismail IZ. Knowledge of female undergraduate students on breast cancer and breast selfexamination in Klang Valley, Malaysia. Asian Pacific journal of cancer prevention: APJCP 
[Internet]. 2015 [cited 2020 Nov 2];16(15):6231-

5. Available from: https://search-ebscohost-com. ezproxy.okcu.edu/login.aspx?direct=true $\mathrm{db}=$ mnh \& $\mathrm{AN}=26434821 \&$ site $=$ ehost-live

5. Hasani L, Aghamolaei T, Tavafian SS, Zare S. Constructs of the Health Belief Model as predicting factors in breast self-examination. HAYAT [Internet]. 2011 Mar [cited 2020 Nov 2];17(1):84. Available from: https://search-ebscohost-com. ezproxy.okcu.edu/login.aspx?direct=true $\quad \&$ $\mathrm{db}=\mathrm{ccm} \& \mathrm{AN}=104703276 \&$ site $=$ ehost-live

6. Yilmaz D, Bebis H, Ortabag T. Determining the awareness of and compliance with breast cancer screening among Turkish residential women. Asian Pacific journal of cancer prevention : APJCP [Internet]. 2013 [cited 2020 Nov 2];14(5):3281-8. Available from: https://search-ebscohost-com. ezproxy.okcu.edu/login.aspx?direct=true $\&$ $\mathrm{db}=$ mnh \& $\mathrm{AN}=23803116 \&$ site $=$ ehost-live

7. Khiyali Z, Aliyan F, Kashfi SH, Mansourian $\mathrm{M}$, \& Jeihooni AK. Educational intervention on breast self-examination behavior in women referred to health centers: Application of Health Belief Model. Asian Pacific journal of cancer prevention [Internet]. 2017 Jan 1 [cited 2020 Nov 2];18(10):2833-8. Available from: https:// search-ebscohost-com.ezproxy.okcu.edu/login. aspx?direct=true $\& \mathrm{db}=\mathrm{cgh} \& \mathrm{AN}=\mathrm{CN}-02093150$ $\&$ site $=$ ehost-live

8. Zare M, Ghodsbin F, Jahanbin I, Ariafar A, Keshavarzi S, Izadi $T$. The Effect of Health Belief Model-Based Education on Knowledge and Prostate Cancer Screening Behaviors: A Randomized Controlled Trial. International Journal of Community Based Nursing \& Midwifery [Internet]. 2016 Jan [cited 2020 Nov 2];4(1):5768. Available from: https://search-ebscohostcom.ezproxy.okcu.edu/login.aspx?direct=true \& $\mathrm{db}=\mathrm{ccm} \& \mathrm{AN}=112161849 \&$ site $=$ ehost-live

9. World Health Organization. 2018. Global cancer burden Retrieved from: https://webcache. googleusercontent.com/search? $\mathrm{q}=$ cache:4B 3kalYxLBUJ:https://www.who.int/cancer/ PRGlobocanFinal.pdf $+\& \mathrm{~cd}=3 \& \mathrm{hl}=$ ar $\& \mathrm{ct}=\mathrm{clnk}$ $\& \mathrm{gl}=\mathrm{iq}, 2018$

10. Kulhánová I, Bray F, Fadhil I, Al-Zahrani AS, ElBasmy A, Anwar WA, et al. Profile of cancer in the Eastern Mediterranean region: The need for action. Cancer epidemiology [Internet]. 2017 Apr [cited 2020 Nov 2];47:125-32. Available from: https:// search-ebscohost-com.ezproxy.okcu.edu/login. aspx?direct $=$ true $\& \mathrm{db}=\mathrm{mnh} \& \mathrm{AN}=28268206 \&$ site $=$ ehost-live 